CRYSTALLOGRAPHIC COMMUNICATIONS

ISSN 2056-9890

Received 11 May 2020

Accepted 15 June 2020

Edited by J. Ellena, Universidade de Sâo Paulo, Brazil

Keywords: crystal structure; isocoumarin; hydrogen bonding; $\mathrm{C}-\mathrm{H} \cdots \pi$ interactions; offset $\pi-\pi$ interactions; supramolecular framework; Hirshfeld surface analysis; energy frameworks.

CCDC reference: 2009890

Supporting information: this article has supporting information at journals.iucr.org/e
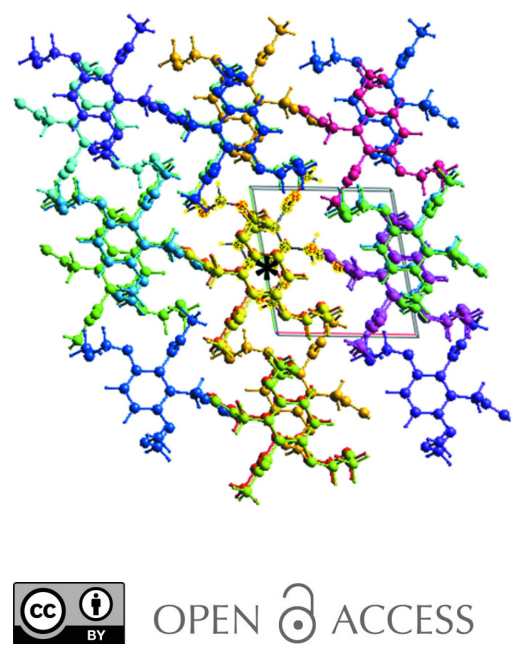

OPEN $\partial$ ACCESS

\section{The crystal structure, Hirshfeld surface analysis and energy frameworks of 2-[2-(methoxycarbonyl)-3,6- bis(methoxymethoxy)phenyl]acetic acid}

\author{
Mustapha Tiouabi, ${ }^{a}$ Raphaël Tabacchi ${ }^{\mathrm{a}}$ and Helen Stoeckli-Evans ${ }^{\mathrm{b} *}$
}

Institute of Chemistry, University of Neuchâtel, Av. de Bellevax 51, CH-2000 Neuchâtel, Switzerland, and ${ }^{\mathbf{b}}$ Institute Physics, University of Neuchâtel, rue Emile-Argand 11, CH-2000 Neuchâtel, Switzerland. *Correspondence e-mail: helen.stoeckli-evans@unine.ch

In the title compound, $\mathrm{C}_{14} \mathrm{H}_{18} \mathrm{O}_{8},(\mathbf{I})$, the methoxycarbonyl $\left[-\mathrm{C}(=\mathrm{O}) \mathrm{OCH}_{3}\right]$ and the acetic acid $\left[-\mathrm{CH}_{2} \mathrm{C}(=\mathrm{O}) \mathrm{OH}\right]$ groups are inclined to the benzene ring by 79.24 (11) and $76.71(13)^{\circ}$, respectively, and are normal to each other with a dihedral angle of $90.00(13)^{\circ}$. In the crystal, molecules are linked by a pair of $\mathrm{O}-\mathrm{H}$. . O hydrogen bonds forming the familiar acetic acid inversion dimer. The dimers are linked by two $\mathrm{C}-\mathrm{H}$. . O hydrogen bonds and an offset $\pi-\pi$ interaction [intercentroid distance $=3.6405(14) \AA$ ], forming layers lying parallel to the $(10 \overline{1})$ plane. The layers are linked by a third $\mathrm{C}-\mathrm{H} \cdots \mathrm{O}$ hydrogen bond and a $\mathrm{C}-\mathrm{H} \cdots \pi$ interaction to form a supramolecular framework.

\section{Chemical context}

Isocoumarins are among the phytotoxins produced by the Ceratocystis fimbriata species. The latter are pathogenic agents responsible for the infections of coffee and plane trees (Gremaud \& Tabacchi, 1994; Bürki et al., 2003). The analysis of the culture medium of Ophiostoma ulmi, a pathogenic agent responsible for elm disease and classified in the family of Ceratocystis, enabled Michel (2001) to isolate sixteen metabolites including four isocoumarins without apparent toxicity and a new natural product, 3-methyl-3,5,8-trihydroxy-3,4-dihydroisocoumarin, found in the extract of diseased wood. Qualitatively, the latter is present in trace amounts; however, the toxicity of this metabolite is possible, since the activity is not necessarily proportional to the concentration.<smiles>COCOc1ccc(OCOC)c(C(=O)OC)c1CC(=O)O</smiles>

The title compound (I), is a key intermediate for the proposed total synthesis of 3-methyl-3,5,8-trihydroxy-3,4-dihydroisocoumarin, and its synthesis is illustrated in Fig. 1 (Tiouabi, 2005). It was synthesized from hydroquinone (1), which was first brominated to give compound 2 . The latter was 


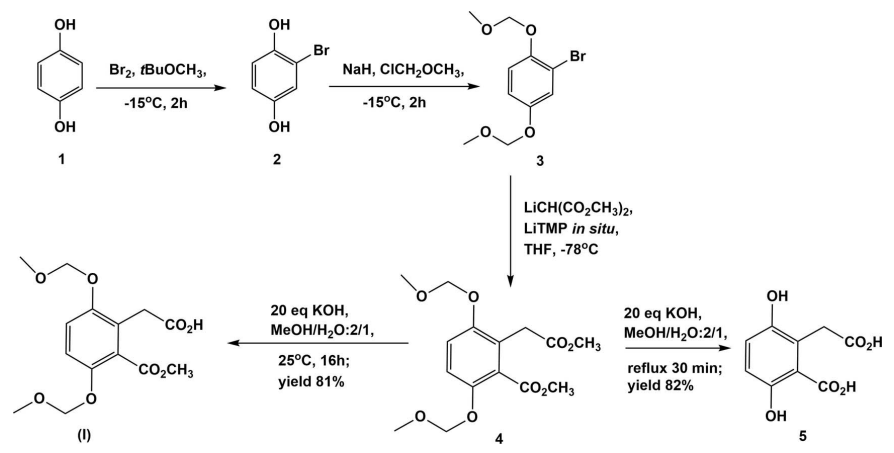

Figure 1

The reaction scheme resulting in the formation of the title compound, I.

then reacted with $\mathrm{NaH}$ and $\mathrm{ClCH}_{2} \mathrm{OCH}_{3}$ to give compound $\mathbf{3}$, so protecting the hydroxyl groups. Reacting $\mathbf{3}$ with tetramethylpiperidene with $n$-butyllithium and $\mathrm{CH}_{2}\left(\mathrm{CO}_{2} \mathrm{CH}_{3}\right)_{2}$ resulted in the formation of compound $\mathbf{4}$. Finally $\mathbf{4}$ was reacted with various quantities of $\mathrm{KOH}$ in methanol/water (2:1) to give the title compound, I. The highest yield (81\%) was obtained by reacting 20 equivalents of $\mathrm{KOH}$ in methanol/ water (2:1) at $298 \mathrm{~K}$ under stirring for $16 \mathrm{~h}$. Interestingly, the same reaction with reflux for 30 minutes yielded the diacid, 2(carboxymethyl)-3,6-dihydroxybenzoic acid (5), with a yield of $82 \%$ (Fig. 1).

\section{Structural commentary}

The molecular structure of compound $\mathbf{I}$ is illustrated in Fig. 2. The methoxymethyl group (mean plane 1: C2/C7/O1/O2/C8; r.m.s. deviation $=0.009 \AA$ ) is inclined to the benzene ring by $79.24(11)^{\circ}$. The plane of the acetic acid unit (mean plane 2:

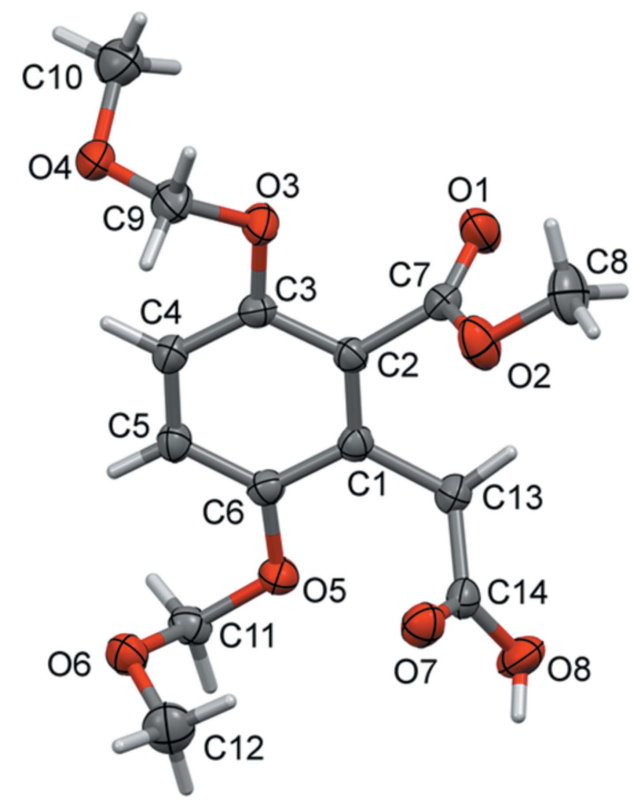

Figure 2

The molecular structure of compound $\mathbf{I}$, with atom labelling. Displacement ellipsoids are drawn at the $50 \%$ probability level.
Table 1

Hydrogen-bond geometry $\left(\AA,^{\circ}\right)$.

$\mathrm{Cg}$ is the centroid of the $\mathrm{C} 1-\mathrm{C} 6$ benzene ring.

\begin{tabular}{lllll}
\hline$D-\mathrm{H} \cdots A$ & $D-\mathrm{H}$ & $\mathrm{H} \cdots A$ & $D \cdots A$ & $D-\mathrm{H} \cdots A$ \\
\hline $\mathrm{O}^{2}-\mathrm{H} 8 \cdots \mathrm{O}^{\mathrm{i}}$ & 0.84 & 1.85 & $2.676(2)$ & 168 \\
$\mathrm{C} 9-\mathrm{H} 9 B \cdots 6^{\mathrm{ii}}$ & 0.99 & 2.43 & $3.256(3)$ & 140 \\
$\mathrm{C}^{\mathrm{i}} 1-\mathrm{H} 11 A \cdots \mathrm{O} 1^{\mathrm{iii}}$ & 0.99 & 2.38 & $3.366(3)$ & 175 \\
$\mathrm{C}^{\mathrm{ii}}-\mathrm{H} 13 B \cdots 4^{\text {iv }}$ & 0.99 & 2.50 & $3.421(3)$ & 155 \\
$\mathrm{C} 12-\mathrm{H} 12 B \cdots C g^{\mathrm{v}}$ & 0.98 & 2.66 & $3.451(3)$ & 138 \\
\hline
\end{tabular}

Symmetry codes: (i) $-x+1,-y+1,-z+1$; (ii) $x, y+1, z$; (iii) $-x,-y+1,-z$; (iv) $x+1, y, z ;(\mathrm{v})-x,-y+1,-z+1$.

$\mathrm{C} 13 / \mathrm{C} 14 / \mathrm{O} 7 / \mathrm{O} 8$; r.m.s. deviation $=0.014 \AA$ ) is inclined to the benzene ring by 76.71 (13) ${ }^{\circ}$. Planes 1 and 2 are normal to each other with a dihedral angle of $90.00(13)^{\circ}$. The methoxymethoxy side chains (O3-C9-O4-C10 and O5-C11-O6-C12) are displaced to opposite sides of the benzene ring. They have twisted conformations as seen from the torsion angles given in Table 3 .

\section{Supramolecular features}

In the crystal of $\mathbf{I}$, molecules are linked by a pair of $\mathrm{O}-\mathrm{H} \cdots \mathrm{O}$ hydrogen bonds $\left(\mathrm{O} 8-\mathrm{H} 8 \cdots \mathrm{O} 7^{\mathrm{i}}\right)$ forming an inversion dimer with an $R_{2}^{2}(8)$ ring motif (Fig. 3 and Table 1). The dimers are linked by two $\mathrm{C}-\mathrm{H} \cdots \mathrm{O}$ hydrogen bonds $\left(\mathrm{C} 9-\mathrm{H} 9 B \cdots \mathrm{O}^{\mathrm{ii}}\right.$ and $\left.\mathrm{C} 11-\mathrm{H} 11 A \cdots \mathrm{O} 1^{\mathrm{iii}}\right)$ and offset $\pi-\pi$ interactions between inversion-related benzene rings, so forming layers lying parallel to $(10 \overline{1})$. The layers are linked by a third $\mathrm{C}-\mathrm{H} \cdots \mathrm{O}$ hydrogen bond $\left(\mathrm{C} 13-\mathrm{H} 13 B \cdots \mathrm{O} 4^{\text {iv }}\right)$ and a $\mathrm{C}-\mathrm{H} \cdots \pi$ interaction to form a supramolecular framework (Table 1 and

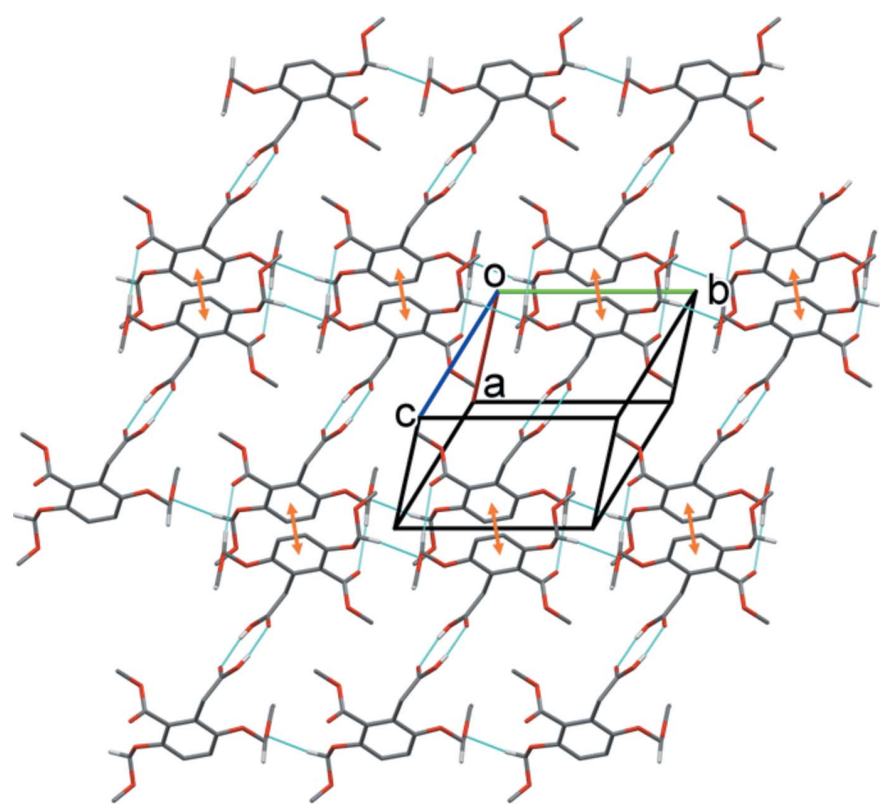

Figure 3

A view normal to plane $(10 \overline{1})$ of the layer structure in the crystal of compound I. Hydrogen bonds (Table 1) are shown as dashed lines and offset $\pi-\pi$ interactions as orange double arrows. For clarity, only the $\mathrm{H}$ atoms involved in the intermolecular interactions have been included. 


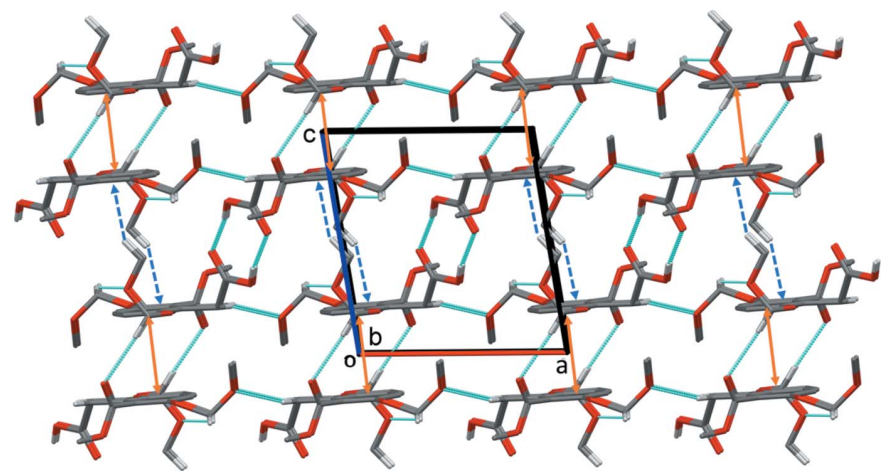

Figure 4

A view along the $b$ axis of the crystal packing of compound I. The hydrogen bonds (Table 1) are shown as dashed lines. The offset $\pi-\pi$ interactions are indicated by orange double arrows, and the $\mathrm{C}-\mathrm{H} \cdots \pi$ interactions by blue dashed arrows. For clarity, only the $\mathrm{H}$ atoms involved in the intermolecular interactions have been included.

Fig. 4). Details of the offset $\pi-\pi$ interaction are as follows: $C g \cdots C g^{\mathrm{iii}}=3.6405$ (14) $\AA$, where $C g$ is the centroid of the $\mathrm{C1}-$ C6 benzene ring; interplanar distance $=3.5911$ (9) $\AA$; offset = $0.597 \AA$ A s symmetry code: (iii) $-x,-y+1,-z$.

\section{Hirshfeld surface analysis and two-dimensional fingerprint plots}

The Hirshfeld surface analysis (Spackman \& Jayatilaka, 2009), the associated two-dimensional fingerprint plots and the calculation of the energy frameworks (McKinnon et al., 2007) were performed with CrystalExplorer17.5 (Turner et al., 2017), following the protocol outlined in the recent article by Tiekink and collaborators (Tan et al., 2019). The Hirshfeld surface is colour-mapped with the normalized contact distance, $d_{\text {norm }}$, from red (distances shorter than the sum of the van der Waals radii) through white to blue (distances longer than the sum of

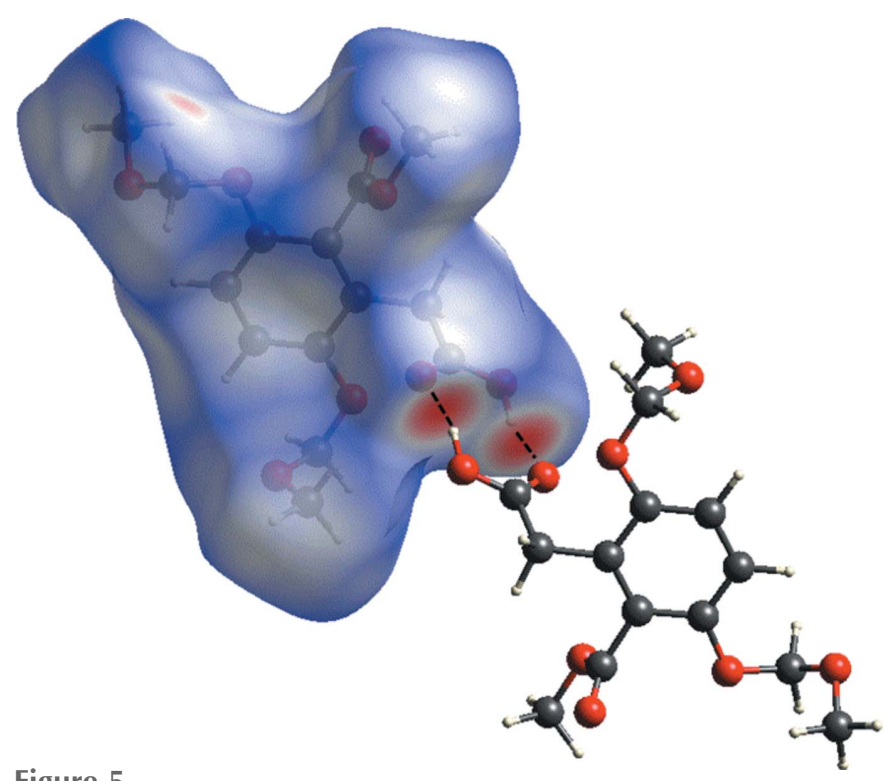

Figure 5

The Hirshfeld surface of compound I mapped over $d_{\text {norm }}$, in the colour range -0.6996 to 1.3669 a.u..
Table 2

Short interatomic contacts $(\AA)^{a}$ in the crystal of compound $\mathbf{I}$.

\begin{tabular}{|c|c|c|c|}
\hline Atom1 & Atom2 & Length & Length $-\mathrm{VdW}$ \\
\hline $\mathrm{O} 7$ & $\mathrm{H} 8^{\mathrm{i}}$ & 1.850 & -0.870 \\
\hline $\mathrm{O} 7$ & $\mathrm{O} 8^{\mathrm{i}}$ & 2.676 & -0.364 \\
\hline $\mathrm{O} 1$ & $\mathrm{H} 11 A^{\mathrm{iii}}$ & 2.379 & -0.341 \\
\hline O6 & $\mathrm{H} 9 B^{\mathrm{vi}}$ & 2.432 & -0.288 \\
\hline $\mathrm{O} 4$ & $\mathrm{H} 13 B^{\mathrm{v}}$ & 2.501 & -0.219 \\
\hline H8 & $\mathrm{C} 14^{\mathrm{i}}$ & 2.703 & -0.197 \\
\hline O5 & $\mathrm{H} 10 C^{\mathrm{iii}}$ & 2.637 & -0.083 \\
\hline $\mathrm{C} 12$ & $\mathrm{H} 9 B^{\mathrm{vi}}$ & 2.882 & -0.018 \\
\hline $\mathrm{O} 4$ & $\mathrm{H} 8 A^{\mathrm{v}}$ & 2.723 & 0.003 \\
\hline $\mathrm{O} 7$ & $\mathrm{C} 8^{\text {viii }}$ & 3.223 & 0.003 \\
\hline $\mathrm{O} 7$ & H8 $B^{\text {viii }}$ & 2.726 & 0.006 \\
\hline $\mathrm{O} 2$ & $\mathrm{H} 8 B^{\mathrm{viii}}$ & 2.731 & 0.011 \\
\hline H8 & $\mathrm{H} 8^{\mathrm{i}}$ & 2.416 & 0.016 \\
\hline $\mathrm{C} 2$ & $\mathrm{H} 12 B^{\mathrm{vii}}$ & 2.932 & 0.032 \\
\hline O6 & $\mathrm{C} 9^{\mathrm{vi}}$ & 3.256 & 0.036 \\
\hline $\mathrm{H} 8 B$ & $\mathrm{C} 14^{\text {viii }}$ & 2.954 & 0.054 \\
\hline C9 & $\mathrm{H} 8 A^{\mathrm{v}}$ & 2.957 & 0.057 \\
\hline $\mathrm{C} 1$ & $\mathrm{H} 12 B^{\mathrm{vii}}$ & 2.968 & 0.068 \\
\hline C3 & H12 $B^{\text {vii }}$ & 2.968 & 0.068 \\
\hline $\mathrm{H} 10 \mathrm{C}$ & $\mathrm{C} 11^{\mathrm{iii}}$ & 2.969 & 0.069 \\
\hline H9B & $\mathrm{H} 8 A^{\mathrm{v}}$ & 2.482 & 0.082 \\
\hline
\end{tabular}

(a) Calculated using Mercury (Macrae et al., 2020). Symmetry codes: (i) $-x+1,-y+1$, $-z+1$; (iii) $-x,-y+1,-z$; (v) $x-1, y, z$; (vi) $x, y-1, z$; (vii) $-x,-y+1,-z+1$; (viii) $-x+1,-y+2,-z+1$.

the van der Waals radii). The energy frameworks (Turner et al., 2015; Tan et al., 2019) are represented by cylinders joining the centroids of molecular pairs using red, green and blue colour codes for the electrostatic $\left(E_{\mathrm{ele}}\right)$, dispersion $\left(E_{\mathrm{dis}}\right)$ and total energy $\left(E_{\text {tot }}\right)$ components, respectively. The radius of the cylinder is proportional to the magnitude of the interaction energy.

A view of the Hirshfeld surface of $\mathbf{I}$ mapped over $d_{\text {norm }}$ is shown in Fig. 5. The short interatomic $\mathrm{O} \cdots \mathrm{H} / \mathrm{H} \cdots \mathrm{O}$ contacts are indicated by the large red spots. Other $\mathrm{C}-\mathrm{H} \cdots \mathrm{O}$ contacts are indicated by faint red spots. A full list of short interatomic contacts in the crystal of $\mathbf{I}$ are given in Table 2 . The majority of the significant contacts are $\mathrm{O} \cdots \mathrm{H}$ and $\mathrm{C} \cdot \mathrm{H}$ contacts, as
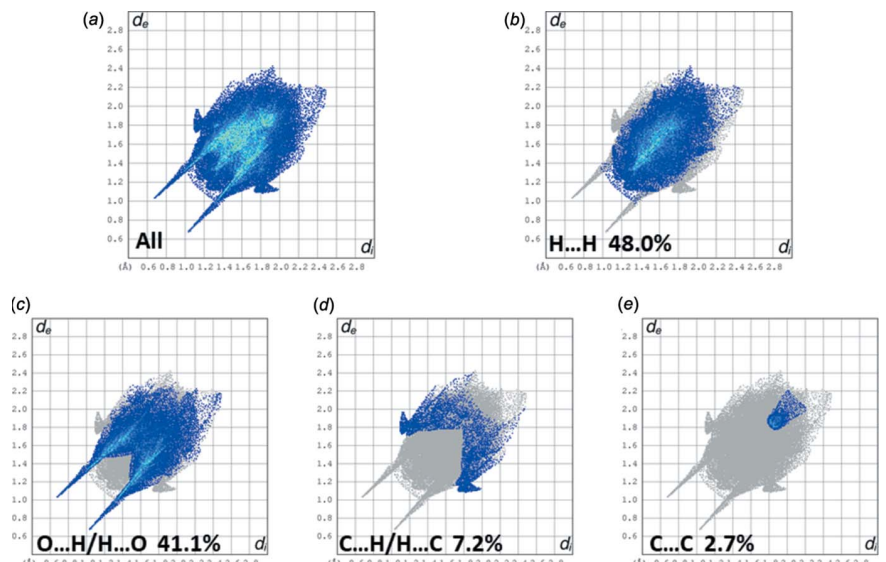

Figure 6

(a) The full two-dimensional fingerprint plot for compound I, and fingerprint plots delineated into $(b) \mathrm{H} \cdots \mathrm{H}(48.0 \%),(c) \mathrm{O} \cdots \mathrm{H} / \mathrm{H} \cdots \mathrm{O}$ $(41.1 \%),(d) \mathrm{C} \cdots \mathrm{H} / \mathrm{H} \cdots \mathrm{C}(7.2 \%)$ and $(e) \mathrm{C} \cdots \mathrm{C}(2.7 \%)$ contacts. 


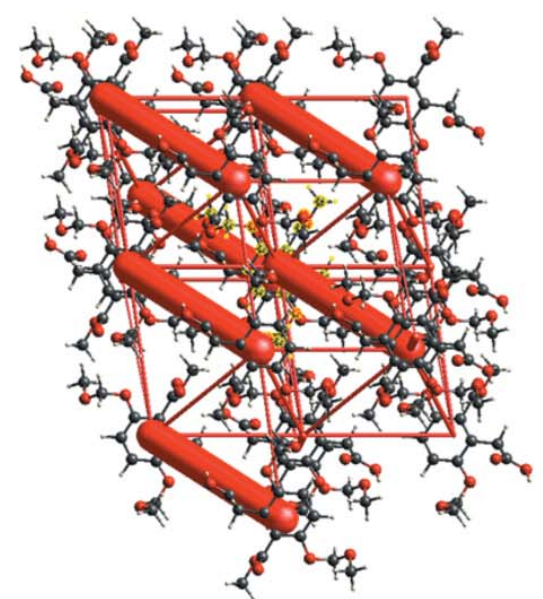

(a)

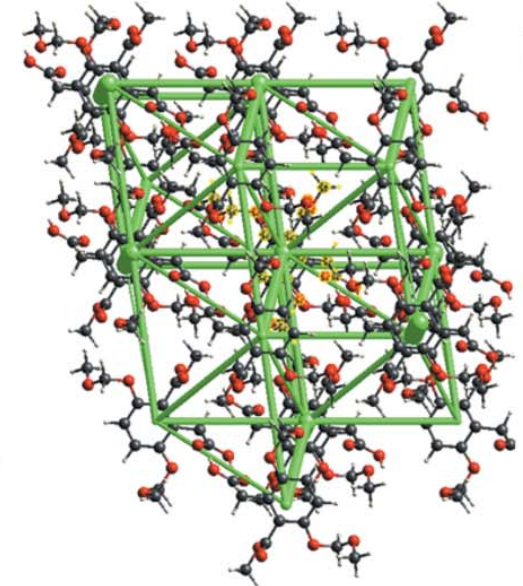

(b)

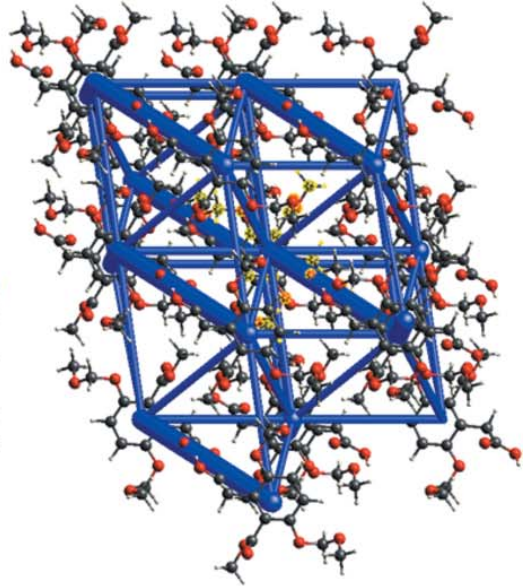

(c)

Figure 7

The energy frameworks for I viewed down the $c$-axis direction comprising, $(a)$ electrostatic potential forces $\left(E_{\text {ele }}\right),(b)$ dispersion forces $\left(E_{\mathrm{dis}}\right)$ and $(c)$ total $\left(E_{\mathrm{tot}}\right)$ energy for a cluster about a reference molecule of $\mathbf{I}$. The energy frameworks were adjusted to the same scale factor of 80 with a cut-off value of $5 \mathrm{~kJ} \mathrm{~mol}^{-1}$ within a $5 \AA$ radius of a selected central molecule.

confirmed by the two-dimensional fingerprint plots (Fig. 6). The principal intermolecular contacts for $\mathbf{I}$ are delineated into $\mathrm{H} \cdots \mathrm{H}(48.0 \%)$ (Fig. 6b), O $\cdots \mathrm{H} / \mathrm{H} \cdots \mathrm{O}(41.1 \%)$ (Fig. 6c), $\mathrm{C} \cdots \mathrm{H} / \mathrm{H} \cdots \mathrm{C}(7.2 \%)$ (Fig. $6 d$ ) and $\mathrm{C} \cdots \mathrm{C}(2.7 \%)$ (Fig. 6e) contacts. The intermolecular contacts are therefore almost equally distributed between electrostatic and dispersion forces, as shown in Fig. $7 a$ and $7 b$. The energy frameworks (Fig. 7) were adjusted to the same scale factor of 80 with a cutoff value of $5 \mathrm{~kJ} \mathrm{~mol}^{-1}$ within a radius of $5 \AA$ about a central molecule, and were obtained using the wave function calculated at the HF/3-21G level of theory.

The calculation of the energy framework results in a colourcoded molecular cluster related to the specific interaction energy, see Fig. $8 a$. The individual energy components, electrostatic $\left(E_{\text {ele }}\right)$, polarization $\left(E_{\mathrm{pol}}\right)$, dispersion $\left(E_{\mathrm{dis}}\right)$ and repulsion $\left(E_{\text {rep }}\right)$ energies and the sum of these components $\left(E_{\mathrm{tot}}\right)$ for the interactions relative to a reference molecule $(*)$ are shown in Fig. $8 b$. (a)

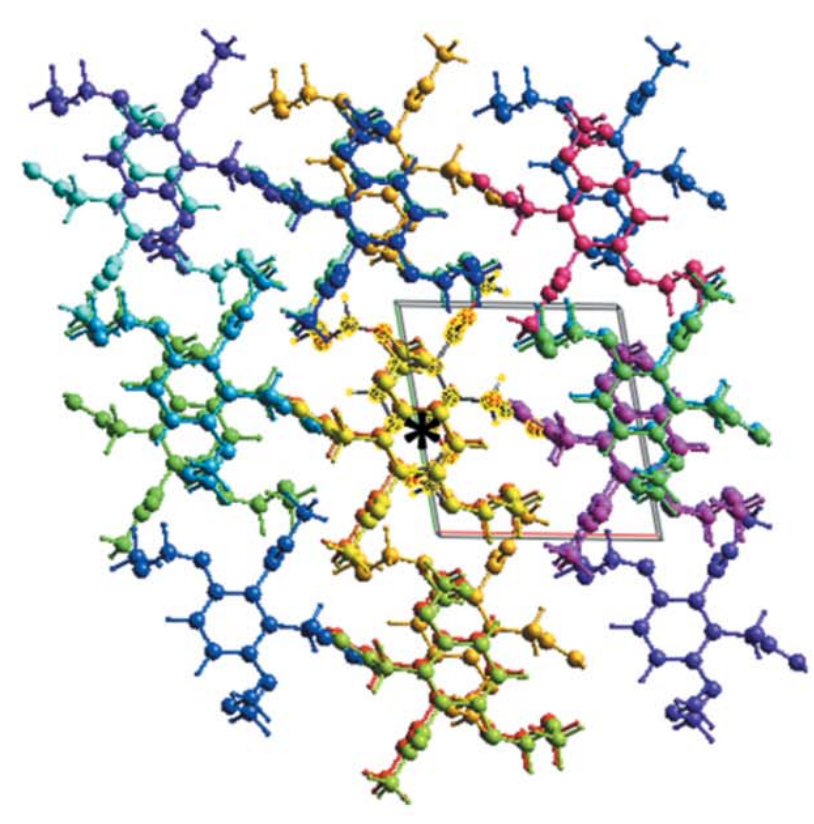

(b)

\begin{tabular}{|r|l|r|l|r|r|r|r|r|}
\hline N & Symop & R & Electron Density & E_ele & E_pol & E_dis & E_rep & E_tot \\
\hline 1 & $-x,-y,-z$ & 11.24 & $H F / 3-21 G$ & 2.6 & -0.5 & -4.0 & 0.4 & -0.9 \\
\hline 1 & $-x,-y,-z$ & 4.62 & $H F / 3-21 G$ & -30.4 & -13.4 & -75.6 & 44.4 & -71.8 \\
\hline 2 & $x, y, z$ & 9.66 & $H F / 3-21 G$ & -12.1 & -4.0 & -28.8 & 16.3 & -27.7 \\
\hline 1 & $-x,-y,-z$ & 6.76 & $H F / 3-21 G$ & 0.4 & -6.6 & -44.4 & 21.9 & -26.1 \\
\hline 1 & $-x,-y,-z$ & 14.98 & $H F / 3-21 G$ & -0.1 & -0.0 & -0.6 & 0.0 & -0.7 \\
\hline 1 & $-x,-y,-z$ & 10.37 & $H F / 3-21 G$ & 0.9 & -0.2 & -5.1 & 0.2 & -3.6 \\
\hline 2 & $x, y, z$ & 12.60 & $H F / 3-21 G$ & -1.5 & -0.1 & -0.8 & 0.0 & -2.3 \\
\hline 1 & $-x,-y,-z$ & 10.16 & $H F / 3-21 G$ & -8.5 & -4.5 & -10.6 & 2.6 & -19.0 \\
\hline 1 & $-x,-y,-z$ & 14.57 & $H F / 3-21 G$ & 1.3 & -0.3 & -4.8 & 2.6 & -1.1 \\
\hline 2 & $x, y, z$ & 8.56 & $H F / 3-21 G$ & -14.4 & -3.9 & -28.2 & 15.0 & -30.5 \\
\hline 2 & $x, y, z$ & 11.99 & $H F / 3-21 G$ & -1.4 & -0.1 & -1.8 & 0.0 & -3.2 \\
\hline 1 & $-x,-y,-z$ & 7.32 & $H F / 3-21 G$ & -15.8 & -3.4 & -18.2 & 4.1 & -31.4 \\
\hline 2 & $x, y, z$ & 13.77 & $H F / 3-21 G$ & 0.4 & -0.1 & -1.0 & 0.0 & -0.5 \\
\hline 1 & $-x,-y,-z$ & 9.05 & $H F / 3-21 G$ & 1.0 & -0.2 & -3.7 & 0.0 & -2.4 \\
\hline 1 & $-x,-y,-z$ & 9.59 & $H F / 3-21 G$ & -113.7 & -37.4 & -17.1 & 100.2 & -74.4 \\
\hline 1 & $-x,-y,-z$ & 8.77 & $H F / 3-21 G$ & -13.9 & -5.9 & -25.0 & 14.4 & -28.9 \\
\hline
\end{tabular}

Figure 8

The colour-coding interaction mapping within $5 \AA$ of the centering $(*)$ molecular cluster. 
Table 3

Selected torsion angles $\left({ }^{\circ}\right)$ in compound I compared to those in compounds GEZPUZ, GEZQAG and IVIQIP.

\begin{tabular}{lr}
\hline I & \\
$\mathrm{C} 3-\mathrm{O} 3-\mathrm{C} 9-\mathrm{O} 4$ & $-77.8(2)$ \\
$\mathrm{C} 10-\mathrm{O} 4-\mathrm{C} 9-\mathrm{O} 3$ & $-67.6(2)$ \\
$\mathrm{C} 6-\mathrm{O} 5-\mathrm{C} 11-\mathrm{O} 6$ & $-61.3(2)$ \\
$\mathrm{C} 12-\mathrm{O} 6-\mathrm{C} 11-\mathrm{O} 5$ & $-65.5(2)$ \\
& \\
$\mathrm{GEZPUZ}$ & \\
$\mathrm{C} 7-\mathrm{O} 4-\mathrm{C} 13-\mathrm{O} 1$ & $67.1(3)$ \\
$\mathrm{C} 16-\mathrm{O} 1-\mathrm{C} 13-\mathrm{O} 4$ & $56.3(3)$ \\
$\mathrm{C} 8-\mathrm{O} 5-\mathrm{C} 12-\mathrm{O} 6$ & $-80.1(2)$ \\
$\mathrm{C} 17-\mathrm{O} 6-\mathrm{C} 12-\mathrm{O} 5$ & $-65.8(3)$ \\
& \\
$\mathrm{GEZQAG}$ & \\
$\mathrm{C} 7-\mathrm{O} 2-\mathrm{C} 12-\mathrm{O} 7$ & $-71.2(8)$ \\
$\mathrm{C} 16-\mathrm{O} 7-\mathrm{C} 12-\mathrm{O} 2$ & $-67.6(9)$ \\
$\mathrm{C} 9-\mathrm{O} 3-\mathrm{C} 10-\mathrm{O} 6$ & $86.1(7)$ \\
$\mathrm{C} 17-\mathrm{O} 6-\mathrm{C} 10-\mathrm{O} 3$ & $76.6(8)$ \\
$\mathrm{IVIOIP}^{b c}$ & \\
$\mathrm{C} 1-\mathrm{O} 1-\mathrm{C} 8-\mathrm{O} 2$ & $-68.9(2)$ \\
$\mathrm{C} 9-\mathrm{O} 2-\mathrm{C} 8-\mathrm{O} 1$ & $-66.1(2)$ \\
\hline
\end{tabular}

(a) Nakayama et al. (2018); (b) Zhang et al. (2017); (c) compound IVIQIP possesses inversion symmetry.

\section{Database survey}

A search of the Cambridge Structural Database (CSD, Version 5.41, last update March 2020; Groom et al., 2016) for the 3,6-bis(methoxymethoxy)phenyl substructure gave only six hits. Three compounds are of particular interest, namely 1-[2-bromo-3,6-bis(methoxymethoxy)phenyl]-1-methoxyheptan-2-ol (CSD refcode GEZPUZ; Nakayama et al., 2018), 7-bromo-4-methoxy-5,8-bis(methoxymethoxy)-3-pentyl-3,4dihydro-1H-2-benzopyran-1-one (GEZQAG; Nakayama et al., 2018) and 2,2'-\{[2,5-bis(methoxymethoxy)-1,4-phenylene]dimethylylidene ddimalononitrile (IVIQIP; Zhang et al., 2017). The first two, GEZPUZ and GEZQAG [compounds 17 and 20 in the publication by Nakayama et al. (2018)], are key intermediates in the synthesis of the dihydroisocoumarin-type natural products, eurotiumide $\mathrm{A}$ and eurotiumide $\mathrm{B}$. Compound IVIQIP [compound 1 $\mathrm{c}$ in the publication by Zhang et al. (2017)] was synthesized in a study of organic solid fluorophores. The conformation of the $-\mathrm{O}-\mathrm{CH}_{2}-\mathrm{O}-\mathrm{CH}_{3}$ side chains are compared to that in compound $\mathbf{I}$ in Fig. 9 and Table 3. In GEZPUZ and GEZQAG these side chains are twisted and directed to the same side of the benzene ring. In IVIQIP they are also twisted but directed to opposite sides of the benzene ring as in compound $\mathbf{I}$.

A search of the CSD for the substructure 2-(2-(methoxycarbonyl)phenyl)acetic acid gave zero hits.

\section{Synthesis and crystallization}

The synthesis of compound $\mathbf{I}$ is illustrated in Fig. 1. Full details of the syntheses and spectroscopic and analytical data for compounds 2-5 and I are available in the $\mathrm{PhD}$ thesis of Tiouabi (2005). It can be downloaded from the website https:// doc.rero.ch/record, a digital library where many theses of
Swiss universities are deposited. Colourless block-like crystals of $\mathbf{I}$ were obtained by slow evaporation of a solution in acetone- $d_{6}$.

\section{Refinement}

Crystal data, data collection and structure refinement details are summarized in Table 4. The $\mathrm{OH}$ and $\mathrm{C}$-bound $\mathrm{H}$ atoms were included in calculated positions and treated as riding atoms: $\mathrm{O}-\mathrm{H}=0.84 \AA, \mathrm{C}-\mathrm{H}=0.95-0.99 \AA$ with $U_{\text {iso }}(\mathrm{H})=$ $1.5 U_{\mathrm{eq}}\left(\mathrm{OH}\right.$ and $\mathrm{C}$-methyl) and $1.2 U_{\mathrm{eq}}(\mathrm{C})$ for other $\mathrm{H}$-atoms.

Intensity data were measured using a Stoe IPDS I, a onecircle diffractometer. For the triclinic system often only $93 \%$ of the Ewald sphere is accessible, which explains why the alert diffrn_reflns_laue_measured_fraction_full value (0.942) below minimum (0.95) is given. This involves 155 random reflections out of the expected 2692 for the IUCr cutoff limit of $\sin \theta / \lambda=$ 0.60 .

\section{Acknowledgements}

RT and HSE are grateful to the University of Neuchâtel for their support over the years.

\section{Funding information}

Funding for this research was provided by: Swiss National Science Foundation and the University of Neuchâtel.

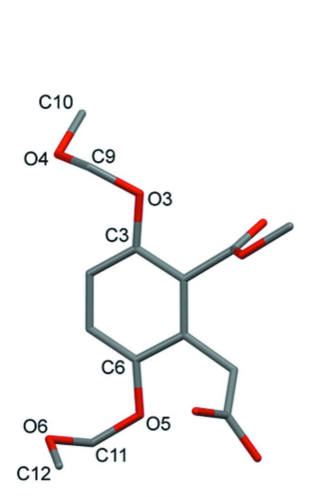

(I)

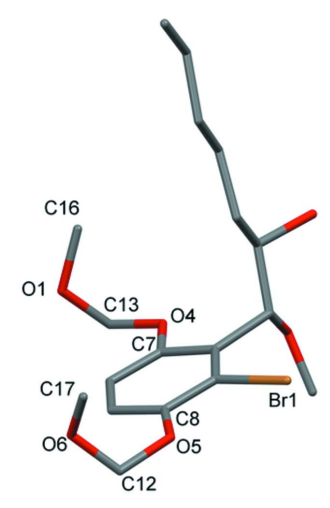

GEZPUZ

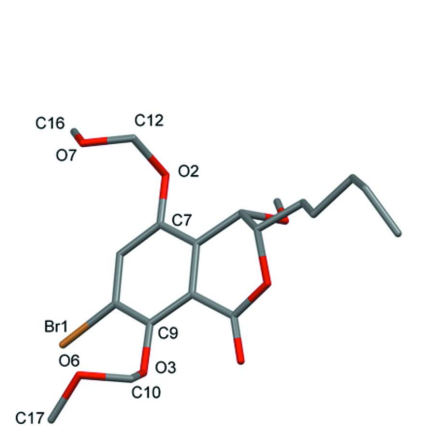

GEZQAG

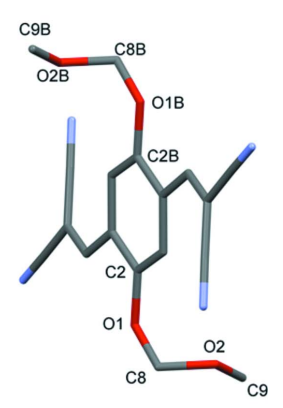

IVIQIP

Figure 9

A view of the molecular structures of I, GEZPUZ, GEZQAGr and IVIQIP. The original atom-labelling schemes have been used for the latter three compounds. For clarity, $\mathrm{H}$ atoms have been omitted 
Table 4

Experimental details.

\begin{tabular}{|c|c|}
\hline Crystal data & \\
\hline Chemical formula & $\mathrm{C}_{14} \mathrm{H}_{18} \mathrm{O}_{8}$ \\
\hline$M_{\mathrm{r}}$ & 314.28 \\
\hline Crystal system, space group & Triclinic, $P \overline{1}$ \\
\hline Temperature $(\mathrm{K})$ & 173 \\
\hline$a, b, c(\AA)$ & $\begin{array}{l}8.5628(12), 9.6623(13) \\
\quad 9.9767(12)\end{array}$ \\
\hline$\alpha, \beta, \gamma\left({ }^{\circ}\right)$ & $\begin{array}{c}112.534(14), 94.744(15), \\
97.999(16)\end{array}$ \\
\hline$V\left(\AA^{3}\right)$ & $746.60(19)$ \\
\hline$Z$ & 2 \\
\hline Radiation type & Mo $K \alpha$ \\
\hline$\mu\left(\mathrm{mm}^{-1}\right)$ & 0.12 \\
\hline Crystal size $(\mathrm{mm})$ & $0.30 \times 0.30 \times 0.20$ \\
\hline Data collection & \\
\hline Diffractometer & Stoe IPDS 1 \\
\hline Absorption correction & $\begin{array}{l}\text { Multi-scan (MULABS; } \\
\text { Spek, 2020) }\end{array}$ \\
\hline$T_{\min }, T_{\max }$ & $0.827,1.000$ \\
\hline $\begin{array}{l}\text { No. of measured, independent and } \\
\text { observed }[I>2 \sigma(I)] \text { reflections }\end{array}$ & $6011,2752,1557$ \\
\hline$R_{\text {int }}$ & 0.065 \\
\hline$(\sin \theta / \lambda)_{\max }\left(\AA^{-1}\right)$ & 0.617 \\
\hline Refinement & \\
\hline$R\left[F^{2}>2 \sigma\left(F^{2}\right)\right], w R\left(F^{2}\right), S$ & $0.045,0.108,0.83$ \\
\hline No. of reflections & 2752 \\
\hline No. of parameters & 204 \\
\hline $\mathrm{H}$-atom treatment & H-atom parameters constrained \\
\hline$\Delta \rho_{\max }, \Delta \rho_{\min }\left(\mathrm{e} \AA^{-3}\right)$ & $0.25,-0.23$ \\
\hline
\end{tabular}

Computer programs: EXPOSE, CELL and INTEGRATE in IPDS-I (Stoe \& Cie, 2004), SHELXS97 (Sheldrick, 2008), Mercury (Macrae et al., 2020), SHELXL2018/3 (Sheldrick, 2015), PLATON (Spek, 2020) and publCIF (Westrip, 2010).

\section{References}

Bürki, N., Michel, A. \& Tabacchi, R. (2003). Phytopathol. Mediterr. 42, 191-198.

Gremaud, G. \& Tabacchi, R. (1994). Nat. Prod. Lett. 5, 95-103.

Groom, C. R., Bruno, I. J., Lightfoot, M. P. \& Ward, S. C. (2016). Acta Cryst. B72, 171-179.

Macrae, C. F., Sovago, I., Cottrell, S. J., Galek, P. T. A., McCabe, P., Pidcock, E., Platings, M., Shields, G. P., Stevens, J. S., Towler, M. \& Wood, P. A. (2020). J. Appl. Cryst. 53, 226-235.

McKinnon, J. J., Jayatilaka, D. \& Spackman, M. A. (2007). Chem. Commun. pp. 3814.

Michel, A. (2001). PhD Thesis. University of Neuchâtel, Switzerland. Nakayama, A., Sata, H., Karanjit, S., Hayashi, N., Oda, M. \& Namba, K. (2018). Eur. J. Org. Chem. pp. 4013-4017.

Sheldrick, G. M. (2008). Acta Cryst. A64, 112-122.

Sheldrick, G. M. (2015). Acta Cryst. C71, 3-8.

Spackman, M. A. \& Jayatilaka, D. (2009). CrystEngComm, 11, 19-32. Spek, A. L. (2020). Acta Cryst. E76, 1-11.

Stoe \& Cie (2004). IPDSI Bedienungshandbuch. Stoe \& Cie GmbH, Darmstadt, Germany.

Tan, S. L., Jotani, M. M. \& Tiekink, E. R. T. (2019). Acta Cryst. E75, 308-318.

Tiouabi, M. (2005). PhD Thesis. University of Neuchâtel, Switzerland. Available from https://doc.rero.ch/record

Turner, M. J., McKinnon, J. J., Wolff, S. K., Grimwood, D. J., Spackman, P. R., Jayatilaka, D. \& Spackman, M. A. (2017). CrystalExplorer17. University of Western Australia. http://hirshfeldsurface.net

Turner, M. J., Thomas, S. P., Shi, M. W., Jayatilaka, D. \& Spackman, M. A. (2015). Chem. Commun. 51, 3735-3738.

Westrip, S. P. (2010). J. Appl. Cryst. 43, 920-925.

Zhang, J. N., Kang, H., Li, N., Zhou, S. M., Sun, H. M., Yin, S. W., Zhao, N. \& Tang, B. Z. (2017). Chem. Sci. 8, 577-582. 


\section{supporting information}

Acta Cryst. (2020). E76, 1101-1106 [https://doi.org/10.1107/S2056989020007987]

\section{The crystal structure, Hirshfeld surface analysis and energy frameworks of}

\section{2-[2-(methoxycarbonyl)-3,6-bis(methoxymethoxy) phenyl]acetic acid}

\section{Mustapha Tiouabi, Raphaël Tabacchi and Helen Stoeckli-Evans}

Computing details

Data collection: EXPOSE in IPDS-I (Stoe \& Cie, 2004); cell refinement: CELL in IPDS-I (Stoe \& Cie, 2004); data reduction: INTEGRATE in IPDS-I (Stoe \& Cie, 2004); program(s) used to solve structure: SHELXS97 (Sheldrick, 2008); program(s) used to refine structure: SHELXL2018/3 (Sheldrick, 2015); molecular graphics: Mercury (Macrae et al., 2020); software used to prepare material for publication: SHELXL2018/3 (Sheldrick, 2015), PLATON (Spek, 2020) and publCIF (Westrip, 2010).

2-[2-(Methoxycarbonyl)-3,6-bis(methoxymethoxy)phenyl]acetic acid

Crystal data

$\mathrm{C}_{14} \mathrm{H}_{18} \mathrm{O}_{8}$ $M_{r}=314.28$

Triclinic, $P \overline{1}$

$a=8.5628(12) \AA$

$b=9.6623(13) \AA$

$c=9.9767(12) \AA$

$\alpha=112.534(14)^{\circ}$

$\beta=94.744(15)^{\circ}$

$\gamma=97.999(16)^{\circ}$

$V=746.60(19) \AA^{3}$

\section{Data collection}

Stoe IPDS 1 diffractometer

Radiation source: fine-focus sealed tube Plane graphite monochromator $\varphi$ rotation scans

Absorption correction: multi-scan

(MULABS; Spek, 2020)

$T_{\text {min }}=0.827, T_{\max }=1.000$

Refinement

Refinement on $F^{2}$ Least-squares matrix: full $R\left[F^{2}>2 \sigma\left(F^{2}\right)\right]=0.045$

$w R\left(F^{2}\right)=0.108$

$S=0.83$

2752 reflections

204 parameters
$Z=2$

$F(000)=332$

$D_{\mathrm{x}}=1.398 \mathrm{Mg} \mathrm{m}^{-3}$

Mo $K \alpha$ radiation, $\lambda=0.71073 \AA$

Cell parameters from 3063 reflections

$\theta=2.2-25.8^{\circ}$

$\mu=0.12 \mathrm{~mm}^{-1}$

$T=173 \mathrm{~K}$

Block, colourless

$0.30 \times 0.30 \times 0.20 \mathrm{~mm}$

6011 measured reflections

2752 independent reflections

1557 reflections with $I>2 \sigma(I)$

$R_{\text {int }}=0.065$

$\theta_{\max }=26.0^{\circ}, \theta_{\min }=2.3^{\circ}$

$h=-10 \rightarrow 10$

$k=-11 \rightarrow 11$

$l=-11 \rightarrow 11$

0 restraints

Primary atom site location: structure-invariant direct methods

Secondary atom site location: difference Fourier map

Hydrogen site location: inferred from neighbouring sites 
$\mathrm{H}$-atom parameters constrained

$w=1 /\left[\sigma^{2}\left(F_{\mathrm{o}}^{2}\right)+(0.0527 P)^{2}\right]$

where $P=\left(F_{\mathrm{o}}^{2}+2 F_{\mathrm{c}}^{2}\right) / 3$

$(\Delta / \sigma)_{\max }<0.001$

$\Delta \rho_{\max }=0.25 \mathrm{e} \AA^{-3}$
$\Delta \rho_{\min }=-0.23$ e $\AA^{-3}$

Extinction correction: (SHELXL2018/3;

Sheldrick, 2015),

$\mathrm{Fc}^{*}=\mathrm{kFc}\left[1+0.001 \mathrm{xFc}^{2} \lambda^{3} / \sin (2 \theta)\right]^{-1 / 4}$

Extinction coefficient: 0.019 (5)

Special details

Geometry. All esds (except the esd in the dihedral angle between two 1.s. planes) are estimated using the full covariance matrix. The cell esds are taken into account individually in the estimation of esds in distances, angles and torsion angles; correlations between esds in cell parameters are only used when they are defined by crystal symmetry. An approximate (isotropic) treatment of cell esds is used for estimating esds involving l.s. planes.

Fractional atomic coordinates and isotropic or equivalent isotropic displacement parameters $\left(\AA^{2}\right)$

\begin{tabular}{|c|c|c|c|c|}
\hline & $x$ & $y$ & $z$ & $U_{\text {iso }} * / U_{\text {eq }}$ \\
\hline $\mathrm{O} 1$ & $0.25754(19)$ & $0.8960(2)$ & $0.1239(2)$ & $0.0457(5)$ \\
\hline $\mathrm{O} 2$ & 0.30589 (19) & $0.94409(18)$ & $0.3608(2)$ & $0.0427(5)$ \\
\hline $\mathrm{O} 3$ & $-0.08148(17)$ & $0.86702(16)$ & $0.21564(19)$ & $0.0354(4)$ \\
\hline $\mathrm{O} 4$ & $-0.36196(18)$ & $0.82093(18)$ & $0.1605(2)$ & $0.0411(5)$ \\
\hline O5 & $0.12039(17)$ & $0.34010(16)$ & $0.18992(18)$ & $0.0313(4)$ \\
\hline O6 & $-0.07328(18)$ & $0.23819(17)$ & $0.29737(19)$ & $0.0357(4)$ \\
\hline $\mathrm{O} 7$ & $0.35707(18)$ & $0.58696(18)$ & $0.45712(19)$ & $0.0373(4)$ \\
\hline O8 & $0.52484(19)$ & $0.4650(2)$ & $0.3133(2)$ & $0.0449(5)$ \\
\hline $\mathrm{H} 8$ & 0.548084 & 0.441888 & 0.384533 & $0.067 *$ \\
\hline $\mathrm{C} 1$ & $0.1715(2)$ & $0.5912(2)$ & $0.2067(2)$ & $0.0255(5)$ \\
\hline $\mathrm{C} 2$ & $0.1204(2)$ & $0.7231(2)$ & $0.2130(2)$ & $0.0255(5)$ \\
\hline $\mathrm{C} 3$ & $-0.0431(2)$ & $0.7295(2)$ & $0.2044(3)$ & $0.0266(5)$ \\
\hline $\mathrm{C} 4$ & $-0.1531(2)$ & $0.6025(2)$ & $0.1876(3)$ & $0.0290(5)$ \\
\hline $\mathrm{H} 4$ & -0.263625 & 0.606043 & 0.179939 & $0.035^{*}$ \\
\hline $\mathrm{C} 5$ & $-0.1034(2)$ & $0.4714(2)$ & $0.1817(3)$ & $0.0292(5)$ \\
\hline H5 & -0.179938 & 0.384882 & 0.170246 & $0.035^{*}$ \\
\hline C6 & $0.0580(2)$ & $0.4643(2)$ & $0.1925(2)$ & $0.0262(5)$ \\
\hline $\mathrm{C} 7$ & $0.2333(2)$ & $0.8614(2)$ & $0.2243(3)$ & $0.0284(5)$ \\
\hline $\mathrm{C} 8$ & $0.4160(3)$ & $1.0825(3)$ & $0.3806(3)$ & $0.0494(7)$ \\
\hline H8A & 0.495875 & 1.056174 & 0.314572 & $0.074^{*}$ \\
\hline H8B & 0.469429 & 1.131775 & 0.482449 & $0.074^{*}$ \\
\hline $\mathrm{H} 8 \mathrm{C}$ & 0.356664 & 1.152557 & 0.357997 & $0.074 *$ \\
\hline $\mathrm{C} 9$ & $-0.2285(3)$ & $0.8986(3)$ & $0.2679(3)$ & $0.0376(6)$ \\
\hline H9A & -0.238127 & 0.869474 & 0.352219 & $0.045^{*}$ \\
\hline H9B & -0.226769 & 1.009573 & 0.303253 & $0.045^{*}$ \\
\hline $\mathrm{C} 10$ & $-0.3713(3)$ & $0.8721(3)$ & $0.0443(3)$ & $0.0509(7)$ \\
\hline H10A & -0.362356 & 0.983164 & 0.085357 & $0.076^{*}$ \\
\hline H10B & -0.473812 & 0.824240 & -0.019781 & $0.076^{*}$ \\
\hline $\mathrm{H} 10 \mathrm{C}$ & -0.284222 & 0.844062 & -0.012623 & $0.076^{*}$ \\
\hline C11 & $0.0113(3)$ & $0.2090(2)$ & 0.1794 (3) & $0.0314(5)$ \\
\hline H11A & -0.065027 & 0.172092 & 0.087538 & $0.038^{*}$ \\
\hline H11B & 0.071162 & 0.126917 & 0.174037 & $0.038^{*}$ \\
\hline $\mathrm{C} 12$ & 0.0227 (3) & $0.2754(3)$ & 0.4335 (3) & $0.0487(7)$ \\
\hline $\mathrm{H} 12 \mathrm{~A}$ & 0.078802 & 0.191711 & 0.426820 & $0.073 *$ \\
\hline
\end{tabular}




\begin{tabular}{|c|c|c|c|c|}
\hline H12B & -0.044987 & 0.291178 & 0.510676 & $0.073^{*}$ \\
\hline $\mathrm{H} 12 \mathrm{C}$ & 0.100661 & 0.368863 & 0.457137 & $0.073 *$ \\
\hline C13 & $0.3446(2)$ & $0.5742(3)$ & $0.2107(3)$ & $0.0313(6)$ \\
\hline H13A & 0.356492 & 0.490502 & 0.118404 & $0.038^{*}$ \\
\hline H13B & 0.409856 & 0.669321 & 0.215295 & $0.038^{*}$ \\
\hline $\mathrm{C} 14$ & $0.4080(2)$ & $0.5412(2)$ & 0.3378 & $0.0305(5)$ \\
\hline
\end{tabular}

Atomic displacement parameters $\left(\AA^{2}\right)$

\begin{tabular}{|c|c|c|c|c|c|c|}
\hline & $U^{11}$ & $U^{22}$ & $U^{33}$ & $U^{12}$ & $U^{13}$ & $U^{23}$ \\
\hline O1 & $0.0385(9)$ & $0.0556(11)$ & 0.0457 (13) & $-0.0099(8)$ & $-0.0036(8)$ & $0.0315(9)$ \\
\hline $\mathrm{O} 2$ & $0.0435(10)$ & $0.0378(9)$ & $0.0348(12)$ & $-0.0124(7)$ & $-0.0001(8)$ & $0.0095(8)$ \\
\hline $\mathrm{O} 3$ & $0.0246(8)$ & $0.0319(8)$ & $0.0551(13)$ & $0.0073(7)$ & $0.0093(7)$ & $0.0217(8)$ \\
\hline $\mathrm{O} 4$ & $0.0259(8)$ & $0.0473(10)$ & $0.0627(14)$ & $0.0081(7)$ & $0.0063(8)$ & $0.0351(9)$ \\
\hline O5 & $0.0300(8)$ & $0.0276(8)$ & $0.0384(11)$ & $0.0054(6)$ & $0.0041(7)$ & $0.0156(7)$ \\
\hline O6 & $0.0350(9)$ & $0.0405(9)$ & $0.0339(12)$ & $0.0031(7)$ & $0.0048(7)$ & $0.0189(8)$ \\
\hline O7 & $0.0339(9)$ & $0.0460(9)$ & $0.0320(12)$ & $0.0076(7)$ & $0.0029(8)$ & $0.0159(8)$ \\
\hline O8 & $0.0354(9)$ & 0.0633 (11) & $0.0482(14)$ & $0.0216(8)$ & $0.0067(8)$ & $0.0311(10)$ \\
\hline $\mathrm{C} 1$ & $0.0224(10)$ & $0.0305(11)$ & $0.0229(14)$ & $0.0026(9)$ & $0.0015(9)$ & $0.0112(9)$ \\
\hline $\mathrm{C} 2$ & $0.0245(11)$ & $0.0282(11)$ & $0.0243(15)$ & $0.0007(9)$ & $0.0016(9)$ & $0.0127(9)$ \\
\hline $\mathrm{C} 3$ & $0.0269(11)$ & $0.0283(11)$ & $0.0281(15)$ & $0.0075(9)$ & $0.0032(9)$ & $0.0144(10)$ \\
\hline $\mathrm{C} 4$ & $0.0219(11)$ & $0.0340(12)$ & $0.0320(16)$ & $0.0036(9)$ & $0.0019(9)$ & $0.0151(10)$ \\
\hline $\mathrm{C} 5$ & $0.0239(11)$ & $0.0299(12)$ & $0.0312(15)$ & $-0.0015(9)$ & $0.0006(9)$ & $0.0123(10)$ \\
\hline C6 & $0.0266(11)$ & 0.0283 (11) & $0.0248(15)$ & $0.0060(9)$ & $0.0022(9)$ & $0.0118(10)$ \\
\hline $\mathrm{C} 7$ & $0.0233(11)$ & $0.0333(12)$ & 0.0313 (16) & $0.0057(9)$ & $0.0019(10)$ & $0.0161(11)$ \\
\hline $\mathrm{C} 8$ & $0.0392(14)$ & 0.0377 (14) & $0.055(2)$ & $-0.0118(11)$ & $0.0019(13)$ & $0.0082(12)$ \\
\hline C9 & $0.0320(12)$ & $0.0371(13)$ & 0.0486 (19) & $0.0120(10)$ & $0.0119(11)$ & $0.0191(12)$ \\
\hline C10 & $0.0426(15)$ & $0.0641(17)$ & $0.060(2)$ & 0.0190 (13) & 0.0137 (13) & $0.0355(15)$ \\
\hline C11 & $0.0370(13)$ & 0.0257 (11) & $0.0293(16)$ & $0.0006(9)$ & $0.0014(10)$ & $0.0111(10)$ \\
\hline $\mathrm{C} 12$ & $0.0506(16)$ & 0.0578 (17) & 0.0354 (19) & $0.0046(13)$ & $0.0034(12)$ & $0.0187(13)$ \\
\hline $\mathrm{C} 13$ & $0.0237(11)$ & $0.0346(12)$ & 0.0395 (17) & $0.0064(9)$ & $0.0054(10)$ & $0.0186(11)$ \\
\hline C14 & $0.0206(11)$ & $0.0317(12)$ & $0.0389(18)$ & $0.0009(9)$ & $0.0013(10)$ & $0.0158(11)$ \\
\hline
\end{tabular}

Geometric parameters $(\AA, \stackrel{o}{)})$

\begin{tabular}{llll}
\hline $\mathrm{O} 1-\mathrm{C} 7$ & $1.196(3)$ & $\mathrm{C} 4-\mathrm{C} 5$ & $1.374(3)$ \\
$\mathrm{O} 2-\mathrm{C} 7$ & $1.329(3)$ & $\mathrm{C} 4-\mathrm{H} 4$ & 0.9500 \\
$\mathrm{O} 2-\mathrm{C} 8$ & $1.461(3)$ & $\mathrm{C} 5-\mathrm{C} 6$ & 0.9500 \\
$\mathrm{O} 3-\mathrm{C} 3$ & $1.379(2)$ & $\mathrm{C} 5-\mathrm{H} 5$ & 0.9800 \\
$\mathrm{O} 3-\mathrm{C} 9$ & $1.429(3)$ & $\mathrm{C} 8-\mathrm{H} 8 \mathrm{~A}$ & 0.9800 \\
$\mathrm{O} 4-\mathrm{C} 9$ & $1.400(3)$ & $\mathrm{C} 8-\mathrm{H} 8 \mathrm{~B}$ & 0.9800 \\
$\mathrm{O} 4-\mathrm{C} 10$ & $1.425(3)$ & $\mathrm{C} 8-\mathrm{H} 8 \mathrm{C}$ & 0.9900 \\
$\mathrm{O} 5-\mathrm{C} 6$ & $1.372(2)$ & $\mathrm{C} 9-\mathrm{H} 9 \mathrm{~A}$ & 0.9900 \\
$\mathrm{O} 5-\mathrm{C} 11$ & $1.429(2)$ & $\mathrm{C} 9-\mathrm{H} 9 \mathrm{~B}$ & 0.9800 \\
$\mathrm{O} 6-\mathrm{C} 11$ & $1.390(3)$ & $\mathrm{C} 10-\mathrm{H} 10 \mathrm{~A}$ & 0.9800 \\
$\mathrm{O} 6-\mathrm{C} 12$ & $1.417(3)$ & $\mathrm{C} 10-\mathrm{H} 10 \mathrm{~B}$ & 0.9800 \\
$\mathrm{O} 7-\mathrm{C} 14$ & $1.240(3)$ & $\mathrm{C} 11-\mathrm{H} 11 \mathrm{C}$ & 0.9900 \\
$\mathrm{O} 8-\mathrm{C} 14$ & $1.308(3)$ & &
\end{tabular}




\begin{tabular}{|c|c|c|c|}
\hline $\mathrm{O} 8-\mathrm{H} 8$ & 0.8400 & $\mathrm{C} 11-\mathrm{H} 11 \mathrm{~B}$ & 0.9900 \\
\hline $\mathrm{C} 1-\mathrm{C} 2$ & $1.386(3)$ & $\mathrm{C} 12-\mathrm{H} 12 \mathrm{~A}$ & 0.9800 \\
\hline $\mathrm{C} 1-\mathrm{C} 6$ & $1.408(3)$ & $\mathrm{C} 12-\mathrm{H} 12 \mathrm{~B}$ & 0.9800 \\
\hline $\mathrm{C} 1-\mathrm{C} 13$ & $1.513(3)$ & $\mathrm{C} 12-\mathrm{H} 12 \mathrm{C}$ & 0.9800 \\
\hline $\mathrm{C} 2-\mathrm{C} 3$ & $1.406(3)$ & $\mathrm{C} 13-\mathrm{C} 14$ & $1.499(3)$ \\
\hline $\mathrm{C} 2-\mathrm{C} 7$ & $1.496(3)$ & $\mathrm{C} 13-\mathrm{H} 13 \mathrm{~A}$ & 0.9900 \\
\hline $\mathrm{C} 3-\mathrm{C} 4$ & $1.383(3)$ & $\mathrm{C} 13-\mathrm{H} 13 \mathrm{~B}$ & 0.9900 \\
\hline $\mathrm{C} 7-\mathrm{O} 2-\mathrm{C} 8$ & 115.27 (19) & $\mathrm{O} 4-\mathrm{C} 9-\mathrm{O} 3$ & $113.0(2)$ \\
\hline $\mathrm{C} 3-\mathrm{O} 3-\mathrm{C} 9$ & $116.23(16)$ & $\mathrm{O} 4-\mathrm{C} 9-\mathrm{H} 9 \mathrm{~A}$ & 109.0 \\
\hline $\mathrm{C} 9-\mathrm{O} 4-\mathrm{C} 10$ & $113.21(19)$ & $\mathrm{O} 3-\mathrm{C} 9-\mathrm{H} 9 \mathrm{~A}$ & 109.0 \\
\hline $\mathrm{C} 6-\mathrm{O} 5-\mathrm{C} 11$ & $117.44(16)$ & $\mathrm{O} 4-\mathrm{C} 9-\mathrm{H} 9 \mathrm{~B}$ & 109.0 \\
\hline $\mathrm{C} 11-\mathrm{O} 6-\mathrm{C} 12$ & $113.99(18)$ & $\mathrm{O} 3-\mathrm{C} 9-\mathrm{H} 9 \mathrm{~B}$ & 109.0 \\
\hline $\mathrm{C} 14-\mathrm{O} 8-\mathrm{H} 8$ & 109.5 & $\mathrm{H} 9 \mathrm{~A}-\mathrm{C} 9-\mathrm{H} 9 \mathrm{~B}$ & 107.8 \\
\hline $\mathrm{C} 2-\mathrm{C} 1-\mathrm{C} 6$ & $119.14(18)$ & $\mathrm{O} 4-\mathrm{C} 10-\mathrm{H} 10 \mathrm{~A}$ & 109.5 \\
\hline $\mathrm{C} 2-\mathrm{C} 1-\mathrm{C} 13$ & $123.33(18)$ & $\mathrm{O} 4-\mathrm{C} 10-\mathrm{H} 10 \mathrm{~B}$ & 109.5 \\
\hline $\mathrm{C} 6-\mathrm{C} 1-\mathrm{C} 13$ & $117.51(18)$ & $\mathrm{H} 10 \mathrm{~A}-\mathrm{C} 10-\mathrm{H} 10 \mathrm{~B}$ & 109.5 \\
\hline $\mathrm{C} 1-\mathrm{C} 2-\mathrm{C} 3$ & $120.27(18)$ & $\mathrm{O} 4-\mathrm{C} 10-\mathrm{H} 10 \mathrm{C}$ & 109.5 \\
\hline $\mathrm{C} 1-\mathrm{C} 2-\mathrm{C} 7$ & $122.31(18)$ & $\mathrm{H} 10 \mathrm{~A}-\mathrm{C} 10-\mathrm{H} 10 \mathrm{C}$ & 109.5 \\
\hline $\mathrm{C} 3-\mathrm{C} 2-\mathrm{C} 7$ & $117.40(18)$ & $\mathrm{H} 10 \mathrm{~B}-\mathrm{C} 10-\mathrm{H} 10 \mathrm{C}$ & 109.5 \\
\hline $\mathrm{O} 3-\mathrm{C} 3-\mathrm{C} 4$ & $124.46(18)$ & $\mathrm{O} 6-\mathrm{C} 11-\mathrm{O} 5$ & $112.89(17)$ \\
\hline $\mathrm{O} 3-\mathrm{C} 3-\mathrm{C} 2$ & $115.83(17)$ & $\mathrm{O} 6-\mathrm{C} 11-\mathrm{H} 11 \mathrm{~A}$ & 109.0 \\
\hline $\mathrm{C} 4-\mathrm{C} 3-\mathrm{C} 2$ & $119.71(18)$ & $\mathrm{O} 5-\mathrm{C} 11-\mathrm{H} 11 \mathrm{~A}$ & 109.0 \\
\hline $\mathrm{C} 5-\mathrm{C} 4-\mathrm{C} 3$ & $120.44(19)$ & $\mathrm{O} 6-\mathrm{C} 11-\mathrm{H} 11 \mathrm{~B}$ & 109.0 \\
\hline $\mathrm{C} 5-\mathrm{C} 4-\mathrm{H} 4$ & 119.8 & $\mathrm{O} 5-\mathrm{C} 11-\mathrm{H} 11 \mathrm{~B}$ & 109.0 \\
\hline $\mathrm{C} 3-\mathrm{C} 4-\mathrm{H} 4$ & 119.8 & $\mathrm{H} 11 \mathrm{~A}-\mathrm{C} 11-\mathrm{H} 11 \mathrm{~B}$ & 107.8 \\
\hline $\mathrm{C} 4-\mathrm{C} 5-\mathrm{C} 6$ & $120.48(18)$ & $\mathrm{O} 6-\mathrm{C} 12-\mathrm{H} 12 \mathrm{~A}$ & 109.5 \\
\hline $\mathrm{C} 4-\mathrm{C} 5-\mathrm{H} 5$ & 119.8 & $\mathrm{O} 6-\mathrm{C} 12-\mathrm{H} 12 \mathrm{~B}$ & 109.5 \\
\hline $\mathrm{C} 6-\mathrm{C} 5-\mathrm{H} 5$ & 119.8 & $\mathrm{H} 12 \mathrm{~A}-\mathrm{C} 12-\mathrm{H} 12 \mathrm{~B}$ & 109.5 \\
\hline $\mathrm{O} 5-\mathrm{C} 6-\mathrm{C} 5$ & $125.22(17)$ & $\mathrm{O} 6-\mathrm{C} 12-\mathrm{H} 12 \mathrm{C}$ & 109.5 \\
\hline $\mathrm{O} 5-\mathrm{C} 6-\mathrm{C} 1$ & $114.84(17)$ & $\mathrm{H} 12 \mathrm{~A}-\mathrm{C} 12-\mathrm{H} 12 \mathrm{C}$ & 109.5 \\
\hline $\mathrm{C} 5-\mathrm{C} 6-\mathrm{C} 1$ & $119.94(19)$ & $\mathrm{H} 12 \mathrm{~B}-\mathrm{C} 12-\mathrm{H} 12 \mathrm{C}$ & 109.5 \\
\hline $\mathrm{O} 1-\mathrm{C} 7-\mathrm{O} 2$ & $122.7(2)$ & $\mathrm{C} 14-\mathrm{C} 13-\mathrm{C} 1$ & $113.74(19)$ \\
\hline $\mathrm{O} 1-\mathrm{C} 7-\mathrm{C} 2$ & $125.0(2)$ & $\mathrm{C} 14-\mathrm{C} 13-\mathrm{H} 13 \mathrm{~A}$ & 108.8 \\
\hline $\mathrm{O} 2-\mathrm{C} 7-\mathrm{C} 2$ & $112.25(19)$ & $\mathrm{C} 1-\mathrm{C} 13-\mathrm{H} 13 \mathrm{~A}$ & 108.8 \\
\hline $\mathrm{O} 2-\mathrm{C} 8-\mathrm{H} 8 \mathrm{~A}$ & 109.5 & $\mathrm{C} 14-\mathrm{C} 13-\mathrm{H} 13 \mathrm{~B}$ & 108.8 \\
\hline $\mathrm{O} 2-\mathrm{C} 8-\mathrm{H} 8 \mathrm{~B}$ & 109.5 & $\mathrm{C} 1-\mathrm{C} 13-\mathrm{H} 13 \mathrm{~B}$ & 108.8 \\
\hline $\mathrm{H} 8 \mathrm{~A}-\mathrm{C} 8-\mathrm{H} 8 \mathrm{~B}$ & 109.5 & $\mathrm{H} 13 \mathrm{~A}-\mathrm{C} 13-\mathrm{H} 13 \mathrm{~B}$ & 107.7 \\
\hline $\mathrm{O} 2-\mathrm{C} 8-\mathrm{H} 8 \mathrm{C}$ & 109.5 & $\mathrm{O} 7-\mathrm{C} 14-\mathrm{O} 8$ & $123.2(2)$ \\
\hline $\mathrm{H} 8 \mathrm{~A}-\mathrm{C} 8-\mathrm{H} 8 \mathrm{C}$ & 109.5 & $\mathrm{O} 7-\mathrm{C} 14-\mathrm{C} 13$ & $122.6(2)$ \\
\hline $\mathrm{H} 8 \mathrm{~B}-\mathrm{C} 8-\mathrm{H} 8 \mathrm{C}$ & 109.5 & $\mathrm{O} 8-\mathrm{C} 14-\mathrm{C} 13$ & $114.1(2)$ \\
\hline $\mathrm{C} 6-\mathrm{C} 1-\mathrm{C} 2-\mathrm{C} 3$ & $-0.3(3)$ & $\mathrm{C} 13-\mathrm{C} 1-\mathrm{C} 6-\mathrm{O} 5$ & $2.6(3)$ \\
\hline $\mathrm{C} 13-\mathrm{C} 1-\mathrm{C} 2-\mathrm{C} 3$ & $178.2(2)$ & $\mathrm{C} 2-\mathrm{C} 1-\mathrm{C} 6-\mathrm{C} 5$ & $1.4(3)$ \\
\hline $\mathrm{C} 6-\mathrm{C} 1-\mathrm{C} 2-\mathrm{C} 7$ & $-178.5(2)$ & $\mathrm{C} 13-\mathrm{C} 1-\mathrm{C} 6-\mathrm{C} 5$ & $-177.2(2)$ \\
\hline $\mathrm{C} 13-\mathrm{C} 1-\mathrm{C} 2-\mathrm{C} 7$ & $0.0(3)$ & $\mathrm{C} 8-\mathrm{O} 2-\mathrm{C} 7-\mathrm{O} 1$ & $1.1(3)$ \\
\hline $\mathrm{C} 9-\mathrm{O} 3-\mathrm{C} 3-\mathrm{C} 4$ & $24.5(3)$ & $\mathrm{C} 8-\mathrm{O} 2-\mathrm{C} 7-\mathrm{C} 2$ & $-178.97(19)$ \\
\hline $\mathrm{C} 9-\mathrm{O} 3-\mathrm{C} 3-\mathrm{C} 2$ & $-154.8(2)$ & $\mathrm{C} 1-\mathrm{C} 2-\mathrm{C} 7-\mathrm{O} 1$ & $99.6(3)$ \\
\hline
\end{tabular}




$\begin{array}{llll}\mathrm{C} 1-\mathrm{C} 2-\mathrm{C} 3-\mathrm{O} 3 & 178.31(19) & \mathrm{C} 3-\mathrm{C} 2-\mathrm{C} 7-\mathrm{O} 1 & -78.6(3) \\ \mathrm{C} 7-\mathrm{C} 2-\mathrm{C} 3-\mathrm{O} 3 & -3.4(3) & \mathrm{C} 1-\mathrm{C} 2-\mathrm{C} 7-\mathrm{O} 2 & -80.3(3) \\ \mathrm{C} 1-\mathrm{C} 2-\mathrm{C} 3-\mathrm{C} 4 & -1.0(3) & \mathrm{C} 3-\mathrm{C} 2-\mathrm{C} 7-\mathrm{O} 2 & 101.5(2) \\ \mathrm{C} 7-\mathrm{C} 2-\mathrm{C} 3-\mathrm{C} 4 & 177.3(2) & \mathrm{C} 10-\mathrm{O} 4-\mathrm{C} 9-\mathrm{O} 3 & -67.6(2) \\ \mathrm{O} 3-\mathrm{C} 3-\mathrm{C} 4-\mathrm{C} 5 & -178.0(2) & \mathrm{C} 3-\mathrm{O} 3-\mathrm{C} 9-\mathrm{O} 4 & -77.8(2) \\ \mathrm{C} 2-\mathrm{C} 3-\mathrm{C} 4-\mathrm{C} 5 & 1.2(3) & \mathrm{C} 12-\mathrm{O} 6-\mathrm{C} 11-\mathrm{O} 5 & -65.5(2) \\ \mathrm{C} 3-\mathrm{C} 4-\mathrm{C} 5-\mathrm{C} 6 & -0.1(3) & \mathrm{C} 6-\mathrm{O}-\mathrm{C} 11-\mathrm{O} 6 & -61.3(2) \\ \mathrm{C} 11-\mathrm{O} 5-\mathrm{C} 6-\mathrm{C} 5 & -1.9(3) & \mathrm{C} 2-\mathrm{C} 1-\mathrm{C} 13-\mathrm{C} 14 & 119.8(2) \\ \mathrm{C} 11-\mathrm{O} 5-\mathrm{C} 6-\mathrm{C} 1 & 178.44(19) & \mathrm{C} 6-\mathrm{C} 1-\mathrm{C} 13-\mathrm{C} 14 & -61.7(3) \\ \mathrm{C} 4-\mathrm{C} 5-\mathrm{C} 6-\mathrm{O} 5 & 179.1(2) & \mathrm{C} 1-\mathrm{C} 13-\mathrm{C} 14-\mathrm{O} 7 & -29.8(3) \\ \mathrm{C} 4-\mathrm{C} 5-\mathrm{C} 6-\mathrm{C} 1 & -1.2(3) & \mathrm{C} 1-\mathrm{C} 13-\mathrm{C} 14-\mathrm{O} 8 & 152.52(19) \\ \mathrm{C} 2-\mathrm{C} 1-\mathrm{C} 6-\mathrm{O} 5 & -178.9(2) & & \end{array}$

Hydrogen-bond geometry $\left(\AA,{ }^{\circ}\right)$

$\mathrm{Cg}$ is the centroid of the $\mathrm{C} 1-\mathrm{C} 6$ benzene ring.

\begin{tabular}{lllll}
\hline$D-\mathrm{H} \cdots A$ & $D-\mathrm{H}$ & $\mathrm{H} \cdots A$ & $D \cdots A$ & $D-\mathrm{H} \cdots A$ \\
\hline $\mathrm{C} 4-\mathrm{H} 4 \cdots \mathrm{O} 4$ & 0.95 & 2.41 & $3.022(3)$ & 122 \\
$\mathrm{O} 8-\mathrm{H} 8 \cdots \mathrm{O} 7^{\mathrm{i}}$ & 0.84 & 1.85 & $2.676(2)$ & 168 \\
$\mathrm{C} 9-\mathrm{H} 9 B \cdots{ }^{\mathrm{ii}}$ & 0.99 & 2.43 & $3.256(3)$ & 140 \\
$\mathrm{C} 11-\mathrm{H} 11 A \cdots \mathrm{O} 1^{\mathrm{iii}}$ & 0.99 & 2.38 & $3.366(3)$ & 175 \\
$\mathrm{C} 13-\mathrm{H} 13 B \cdots \mathrm{O} 4^{\text {iv }}$ & 0.99 & 2.50 & $3.421(3)$ & 155 \\
$\mathrm{C} 12-\mathrm{H} 12 B \cdots \mathrm{Cg}^{\mathrm{v}}$ & 0.98 & 2.66 & $3.451(3)$ & 138
\end{tabular}

Symmetry codes: (i) $-x+1,-y+1,-z+1$; (ii) $x, y+1, z$; (iii) $-x,-y+1,-z$; (iv) $x+1, y, z$; (v) $-x,-y+1,-z+1$. 